\title{
EFFICACY OF GLYPHOSATE HERBICIDE AGAINST DODDER AND ITS IMPACT ON SOME BIOCHEMICAL PARAMETERS ON HOST PLANT Nerium oleander L. AND A SURVEY OF HOST RANGE OF SOME ORNAMENTALS AT FAYOUM.
}

(Received: 15. 6. 2011)

\author{
By \\ I.H.H. Ali and M.A. El-Yazal * \\ Plant Protection Department and * Botany Department, Faculty of Agriculture, \\ Fayoum University, Egypt.
}

\begin{abstract}
Post - attachment applications of glyphosate at low rates (200 and $400 \mathrm{ppm}$ ) controlled (86-90\%) of attached dodder, Cuscuta campestris Yunker on Nerium oleander L. after two months of the treatment without any phytotoxicity. Also, glyphosate at the same rates reduced seed germination, length and fresh weight of dodder. Moreover, both glyphosate at the rates (200 and $400 \mathrm{ppm}$ ) increased leaf area, leaf fresh weight and percentage of leaves dry weight of $N$. oleander as compared to the check. The obtained results also indicated that both rates of the herbicide markedly increased the leaf contents from total carbohydrate, total reducing and non reducing sugars, chlorophylls, carotenoid, xanthophylls, prolin, total indoles, ascorbic acid and antioxidant enzymes activity in the leaves. On the contrary, all dodder control treatments decreased free phenols in the leaves as compared to the check. On the other hand, this parasite was found attacking eleven ornamental plants belonging to different families at Fayoum Governorate. Some of these hosts were new recording as susceptible hosts by $C$. campestris in Egypt. These new hosts included five ornamentals: Nerium oleander L., Adhatoda vasica L., Ficus nitida L., Ipomoea horsfalliae L. and Cestrum diurnum L.
\end{abstract}

Key words: antioxidant enzymes, chemical constituents, dodder control, glyphosate, Nerium oleander, ornamentals.

\section{INTRODUCTION}

The genus Cuscuta contains numerous species, all of which are known in English by the common name "dodder". All species of Cuscuta are obligate stem and leaf parasites. The field dodder (C. campestris Yunker.) a parasitic weed is one of several dodder species present in the flora of Egypt (Parker and Wilson, 1986). This species is a parasite not only of many crops and vegetables but also of numerous ornamental species. Also, the field dodder is the most widespread agricultural problem of all Cuscuta species, one plant is capable of producing several thousand seeds (Gimesi, 1966, 1987). The dodder seedlings have twined about a host plant, haustoria from the parasite soon penetrate the stem and leaf of the host. Vascular cells of the parasite contact those cells of the host and the materials from the phloem and xylem of the host are diverted into the parasite which grows rapidly and becomes large, while the host plant is severely damaged or killed (Dawson, 1987; Christopher et al., 2009 ). Cuscuta plants can be killed by cutting or removed the host plants or by spraying the host and parasite with a selective herbicide. Among the herbicides which were screened for their activity on field dodder, glyphosate. Lethal quantities of glyphosate reach the dodder by direct contact and by translocation from the host to the parasite (Dawson and Saghir, 1983). Glyphosate is a standard herbicide because it controlled Cuscuta selectively at the very low rates 75 to $150 \mathrm{~g} / \mathrm{ha}$ to alfalfa foliage (Dawson, 1990). Fenugreek plants (Ali and El-Yazal, 2003), clover (Soliman and Abd El-Hamid, 2009), at 50 ppm to citrus trees (Abu-Irmaileh and Fuilk, 1989) and at $300 \mathrm{ppm}$ to some ornamental plants (Hock et al., 2008). The objective of this research was to determine the proper rates of glyphosate herbicide that would control dodder without causing phytotoxicity to N.oleander shrubs as well as the effect of herbicide on some biochemical constituents and antioxidants enzymes for the host in addition to recognise the host range of field dodder at Fayoum Governorate. 


\subsection{Field experiments}

2. MATERIALS AND METHODS

In April 2009, the heavy infestations of field dodder ( $C$. campestris) on evergreen shrubs of N.oleander at Fayoum (Keman fars region) were sprayed with Herbazed (glyphosate $48 \%$ WSC) at several levels 50, 100, 200, 400 and 800 ppm. Only one treatment per shrub was applied to the N.oleander because of the limited number of infested shrubs. Each branch represented one replicate ( 4 branches / shrub), the treated shrubs were marked by an adhesive tape, treatments were replicated four times. The data were recorded after 2, 4 and 8 weeks to evaluate the level of dodder control. Dodder control was measured by counting the attached dodder that wrapped around the host and produced visible haustoria according to (Dawson, 1972) as follows:

Control percentage $=100-\frac{\text { (No. attached dodder in treatment })}{\text { (No. attached dodder in check) }} \times 100$

\subsection{Laboratory experiments}

Dodder seed germination was tested in the laboratory, seed lots were collected from each glyphosate treated dodder and untreated check. Mature seeds were selected from each lot for germination and growth. The seeds were dipped for 25 minutes in concentrated sulfuric acid, washed with tap water, air dried before use (Graph et al., 1987). Twenty five seeds per dish were placed on filter paper moistened with $3 \mathrm{ml} /$ dish of distilled water. Dishes were covered and incubated at $25 \pm 2^{\circ} \mathrm{C}$. Germination percentages were counted after 10 days of incubation. The shoots were excised at the seed level and their length were calculated. Shoot fresh weight was also recorded (Giannopolitis, 1979).

\subsection{Data recorded}

\subsubsection{Growth character}

For each treatment, host leaf samples were collected in the morning after 70 days post spraying. Samples of each treatment were taken and the average of the following characters were recorded: fresh and dry weight of leaf $(\mathrm{g})$ and total leaf area $\left(\mathrm{cm}^{2}\right)$ was estimated by using an area meter, model Li 3000 from LICORE, USA.

\subsubsection{Chemical analysis}

For each treatment, host leaf samples were collected in the morning after 70 days from spraying. Each sample was analyzed twice for: photosynthetic pigments (chlorophyll a, b and caroteniods) as $\mathrm{mg} / \mathrm{g}$ fresh weight was extracted from fresh leaves by acetone $(80 \%)$ then, their concentrations were determined according to Welburn and Lichtenthaler (1984). Total carbohydrates as $\mathrm{mg} / \mathrm{g}$ dry weight was extracted by sulphuric acid $(0.1 \mathrm{~N})$ then determined colorimetrically by using phenol-sulphuric acid reagent according to the method described by (Michel et al., 1956), total and reducing sugars as $\mathrm{mg} / \mathrm{g}$ dry weight were determined in ethanolic extract using phosphomolybdic acid reagent as described by (A.O.A.C., 1995), total indoles as $\mathrm{mg} / \mathrm{g}$ dry weight were determined in ethanolic extract using 4-dimethyl- amino- benzaldehyde reagent as described by (Larson et al., 1962), free proline concentration as $\mathrm{mg} / \mathrm{g}$ dry weight was extracted by sulfosalicylic acid then determined colorimetrically using acid ninhydrin and toluene reagent as described by (Bates et al., 1973), ascorbic acid as $\mathrm{mg} / 100 \mathrm{~g}$ fresh weight was extracted by metaphosphoric acid then, determined using 2,6- dichlorophenol indophenol as described by (A.O.A.C., 1995). Total and free phenols as $\mathrm{mg} / \mathrm{g}$ dry weight were determined in ethanolic extract using Folin-Denis reagent as described by (A.O.A.C., 1995). Peroxidase activity was determined by the method described by (Maehly and Chance, 1954), catalase activity was determined by the method described by (Beers and Sizer, 1952). Polyphenol oxidase was determined according to (Taneja and Sachar, 1974) and ascorbic acid oxidase was determined according to (Dawson and Magee, 1955).

\subsection{The host range of C.campestris}

Field survey was carried out to study the host range of $C$. campestris at Fayoum Governorate. The susceptible hosts of ornamental plants were collected from various areas to determine its spread. Specimens were brought to the laboratory for proper identification, and parasitism was qualified by the presence of sucker attachments.

\subsection{Statistical analysis}

All data were statistically analyzed according to Snedecor and Cochran (1980). Means were compared using the least significant difference (L.S.D.) test at 0.05 significance level.

\section{RESULTS AND DISCUSSION \\ 3.1. Dodder control}

The data in Table (1) show that glyphosate at 200 and 400 ppm controlled 86 and $90 \%$ of dodder within two months of application without any injury to the shrubs of $N$. oleander. Glyphosate at the rate of 400 ppm exhibited a higher control for dodder than the rate of 200 ppm. However, this difference is not significant even at the 0.01 level. The efficiency of both glyphosate rates was more or less the same. Although glyphosate at the higher rate $(800 \mathrm{ppm})$ caused $95 \%$ control but phytotoxic effect on the 
Table (1): Control percentage of dodder measured periodically after the application of glyphosate on N.oleander.

\begin{tabular}{|c|c|c|c|c|c|}
\hline \multirow{3}{*}{ Treatment } & \multirow{2}{*}{ Conc. (ppm) } & \multicolumn{4}{|c|}{ Control percentage } \\
\cline { 3 - 6 } & & \multicolumn{3}{|c|}{ Weeks after application } & \multirow{2}{*}{ Mean } \\
\cline { 2 - 6 } & & $\mathbf{2}$ & $\mathbf{4}$ & $\mathbf{8}$ & $(-)$ \\
\hline Check & - & $(-)$ & $(-)$ & $(-)$ & 32.1 \\
\cline { 2 - 6 } Glyphosate & 50 & 58.4 & 38.0 & $(-)$ & 54.6 \\
\cline { 2 - 6 } & 100 & 75.0 & 59.0 & 29.8 & 86.0 \\
\cline { 2 - 6 } & 200 & 94.1 & 90.2 & 73.7 & 90.0 \\
\cline { 2 - 6 } & 400 & 100 & 90.8 & 79.3 & - \\
\cline { 2 - 6 } & 800 & 100 & 100 & $\mathbf{1 0 . 7 3}$ & - \\
\cline { 2 - 6 } & - & $\mathbf{1 9 . 0 4}$ & $\mathbf{1 5 . 6 2}$ & & \\
\hline
\end{tabular}

host plant was observed, while at the lower rate (50 ppm) had little or no significant effect on dodder $(32.1 \%$ control). Therefore, the injury of the host was due to dodder infection and not to the side effect of the herbicide activity. Thus, glyphosate rates at 200 or $400 \mathrm{ppm}$ are recommended for use in $N$. oleander without inducing any phytotoxicity.

The data in Table (2) reveal that glyphosate caused significant reduction in seed germination of dodder to $69.0,60.5$ and $47.3 \%$ at 200, 400 and $800 \mathrm{ppm}$, respectively, while it was $92 \%$ in the check treatment. Also, the length of dodder seedling was reduced to $8.0,7.3$ and $5.8 \mathrm{~cm}$ and the fresh weight to $0.095,0.092$ and $0.084 \mathrm{mg}$ at the same rates, respectively, whereas the length and fresh weight were $10.5 \mathrm{~cm}$ and $0.146 \mathrm{mg}$ in the control. This decrease was not significant at the lower rates (50 and $100 \mathrm{ppm}$ ) of glyphosate. These results indicate that the low rates (200 or $400 \mathrm{ppm}$ ) of glyphosate could control field dodder selectively in $N$. oleander after the parasite is attached to the host plant. These results are in line with those of Zahran et al. (1995) who found that the best treatments for the dodder control on duranta shrubs were glyphosate + herbex $(500+$ $500 \mathrm{ppm})$ or glyphosate + scepter $(500+500$ ppm). Both treatments killed $100 \%$ of C.campestris. Also, Abu-Irmaileh (1987) showed that glyphosate gave excellent control of dodder (C.monogyna) on citrus at rates as low as $50 \mathrm{ppm}$ within four months without harming citrus trees. Seed germination and growth of dodder were affected significantly by glyphosate treatments at 100 ppm and higher. Bewick et al. (1988) mentioned that glyphosate controlled dodder selectively in cranberry and carrot after the parasite is attached to the host plant. They added that large amount of dodder tissue (threads and seeds) present on the host plant may have it protected from the harmful effects of glyphosate application. Giannopolitis (1979) reported that ethofumesate is a potent inhibitor of dodder seed germination and stem elongation. Metolachlor and propyzamide are also active inhibitors but at higher concentrations than ethofumesate.

\subsection{Growth characters}

Data in Table (3) show that all treatments of glyphosate improved the growth of N.oleander compared with the infected untreated plants and reduced the adverse effect of dodder on leaf area. The best results were obtained by applying glyphosate at 200 and $400 \mathrm{ppm}$. The increases gained were 21.55 and $25.53 \%$ more than the check, respectively. Also, the increments in leaf fresh weights were 11.16 and $14.42 \%$ and leaf dry weights were 47.57 and $58.10 \%$ at 200 and 400 ppm more than the check, respectively.

\subsection{Chemical constituents}

\subsubsection{Pigment concentrations in the leaves}

The data presented in Table (4) indicate that treating plants with glyphosate at 200 and 400 ppm increased the plastid pigments significantly compared to the check. The increases were 14.27 and $23.15 \%$ for chlorophyll a; 43.89 and $53.05 \%$ for chlorophyll b; 68.75 and $87.50 \%$ for total carotenoids and 81.08 and $91.89 \%$ for xanthophyll over the check, respectively.

\subsubsection{Carbohydrate concentrations in the leaves}

The data in Table (5) reveal that concentrations of total carbohydrates in the leaves were significantly decreased due to dodder infection. On the contrary, total carbohydrate concentrations were increased due to glyphosate treatments. The maximum increases obtained by glyphosate at 200 and $400 \mathrm{ppm}$ were 57.26 and $60.99 \%$ for total carbohydrate. While, these increases were 46.04 and $51.45 \%$ for total sugars and 17.86 and $31.46 \%$ for reducing sugars. Regarding the concentration of non reducing sugars in leaves, the higher increase was obtained by glyphosate at 200 and $400 \mathrm{ppm}$. This increase reached 78.07 and $74.17 \%$ over the check, respectively. 
Table (2): Effect of glyphosate applications on seed germination, length and fresh weight of dodder seedlings.

\begin{tabular}{|l|c|c|c|c|}
\hline \multirow{4}{*}{ Treatment } & $\begin{array}{c}\text { Conc. } \\
(\mathbf{p p m})\end{array}$ & $\begin{array}{c}\text { Seed germination } \\
(\mathbf{\%})\end{array}$ & $\begin{array}{c}\text { Length } \\
(\mathbf{c m})\end{array}$ & $\begin{array}{c}\text { Fresh weight } \\
(\mathbf{m g})\end{array}$ \\
\hline Check & - & 92.0 & 10.5 & 0.146 \\
\cline { 2 - 5 } Glyphosate & 50 & 85.3 & 11.3 & 0.153 \\
\cline { 2 - 5 } & 100 & 82.7 & 10.0 & 0.128 \\
\cline { 2 - 5 } & 200 & 69.0 & 8.0 & 0.095 \\
\cline { 2 - 5 } & 400 & 60.5 & 7.3 & 0.092 \\
\cline { 2 - 5 } L.S.D. 0.05 & 800 & 47.3 & 5.8 & 0.084 \\
\cline { 2 - 5 } & - & $\mathbf{9 . 9 6}$ & $\mathbf{1 . 6 4}$ & $\mathbf{0 . 0 3 2}$ \\
\hline
\end{tabular}

Table (3): Effect of glyphosate herbicide on the growth of $N$.oleander leaves.

\begin{tabular}{|l|c|c|c|c|}
\hline \multicolumn{1}{|c|}{ Treatment } & $\begin{array}{c}\text { Conc. } \\
(\mathbf{p p m})\end{array}$ & $\begin{array}{c}\text { Total leaf area } \\
(\mathbf{c m})\end{array}$ & $\begin{array}{c}\text { Leaf fresh } \\
\text { weight }(\mathbf{g})\end{array}$ & $\begin{array}{c}\text { Dry weight of } \\
\text { leaves (\%) }\end{array}$ \\
\hline Check & - & 25.66 & 2.15 & 21.65 \\
\cline { 2 - 5 } Glyphosate & 50 & 28.15 & 2.24 & 22.44 \\
\cline { 2 - 5 } & 100 & 29.96 & 2.30 & 29.23 \\
\cline { 2 - 5 } & 200 & 31.19 & 2.39 & 31.95 \\
\cline { 2 - 5 } & 400 & 32.21 & 2.46 & 34.23 \\
\cline { 2 - 5 } L.S.D. 0.05 & 800 & 27.17 & 2.25 & 24.08 \\
\cline { 2 - 5 } & - & $\mathbf{1 . 6 6}$ & $\mathbf{0 . 0 9}$ & $\mathbf{3 . 1 5}$ \\
\hline
\end{tabular}

Table (4): Effect of glyphosate herbicide on chlorophyll a,b, carotenoids and xanthophyll of N.oleander leaves.

\begin{tabular}{|l|c|c|c|c|c|}
\hline \multirow{3}{*}{ Treatment } & Conc. $(\mathbf{p p m})$ & $\begin{array}{c}\text { Chlorophyll } \\
(\mathbf{A}) \mathbf{~ m g} / \mathbf{g}\end{array}$ & $\begin{array}{c}\text { Chlorophyll } \\
(\mathbf{B}) \mathbf{~ m g} / \mathbf{g}\end{array}$ & $\begin{array}{c}\text { Carotenoides } \\
\mathbf{~ m g / g}\end{array}$ & $\begin{array}{c}\text { Xanthophyll } \\
\mathbf{~ m g / g}\end{array}$ \\
\hline Check & - & 1317 & 262 & 112 & 37 \\
\cline { 2 - 6 } Glyphosate & 50 & 1477 & 349 & 122 & 42 \\
\cline { 2 - 6 } & 100 & 1489 & 356 & 148 & 52 \\
\cline { 2 - 6 } & 200 & 1505 & 377 & 189 & 67 \\
\cline { 2 - 6 } & 400 & 1622 & 401 & 210 & 71 \\
\cline { 2 - 6 } & 800 & 1357 & 219 & 119 & 40 \\
\cline { 2 - 6 } L.S.D. 0.05 & - & $\mathbf{1 1 8}$ & $\mathbf{3 0 . 6}$ & $\mathbf{2 4 . 1}$ & $\mathbf{5 . 7 0}$ \\
\hline
\end{tabular}

Table (5): Effect of glyphosate herbicide on total carbohydrate, total, reducing and non reducing sugars of N.oleander leaves.

\begin{tabular}{|c|c|c|c|c|c|}
\hline Treatment & $\begin{array}{c}\text { Conc. } \\
\text { (ppm) }\end{array}$ & $\begin{array}{c}\text { Total } \\
\text { carbohydrate } \\
\mathbf{m g} / \mathbf{g}\end{array}$ & $\begin{array}{c}\text { Total sugars } \\
\mathbf{m g} / \mathbf{g}\end{array}$ & $\begin{array}{c}\text { Reducing } \\
\text { sugars mg/g }\end{array}$ & $\begin{array}{c}\text { Non } \\
\text { reducing } \\
\text { sugars mg/g }\end{array}$ \\
\hline \multirow{3}{*}{$\begin{array}{c}\text { Check } \\
\text { Glyphosate }\end{array}$} & - & 241 & 25.15 & 13.38 & 11.77 \\
\cline { 2 - 6 } & 50 & 304 & 31.73 & 14.32 & 17.41 \\
\cline { 2 - 6 } & 100 & 337 & 32.24 & 14.74 & 17.50 \\
\cline { 2 - 6 } & 200 & 379 & 36.73 & 15.77 & 20.96 \\
\cline { 2 - 6 } & 400 & 388 & 38.09 & 17.59 & 20.50 \\
\cline { 2 - 6 } L.S.D. 0.05 & 800 & 235 & 25.85 & 10.53 & 15.32 \\
\cline { 2 - 6 } & - & $\mathbf{1 2 . 2}$ & $\mathbf{2 . 0 7}$ & $\mathbf{1 . 9 3}$ & $\mathbf{2 . 1 6}$ \\
\hline
\end{tabular}




\subsubsection{Free prolin, total indoles, ascorbic acid, total and free phenoles}

Data in Table (6) show that free prolin, total indoles, ascorbic acid and total phenol in the leaves were decreased in the plants of N.oleander infected with dodder. In contrast, applying glyphosate at 200 and $400 \mathrm{ppm}$ increased these constituents. The increases gained were 23.52 and $31.20 \%$ in free prolin; 75.15 and $77.89 \%$ in total indoles; 44.33 and $47.98 \%$ in ascorbic acid and 66.79 and $71.40 \%$ in total phenol over the check, respectively. On the other hand, free phenol concentrations were decreased by 10.78 and $12.63 \%$ at 200 and $400 \mathrm{ppm}$ under the check, respectively.
The positive effect of glyphosate on growth characters of N.oleander infected plants may be due to the role of the herbicide in controlling dodder selectively after the parasite is attached to the host plant (Dawson, 1990) which improve early plant growth, the rate of essential nutrients absorption, e.g., (N.P.K.). and the increase in plant growth, hormones such as indole acetic acid. In this respect, Dawson and Saghir (1983) and ElSaht et al. (1994) generally reported that herbicides effect on plant growth was found to be associated with marked changes in the metabolism of the treated plants. Also, they added that lethal quantities of herbicide reach the dodder by translocation from the host to the parasite.

Table (6): Effect of glyphosate herbicide on some chemical constituents of N.oleander leaves.

\begin{tabular}{|c|c|c|c|c|c|c|}
\hline \multirow{4}{*}{$\begin{array}{c}\text { Treatment } \\
\text { Check }\end{array}$} & $\begin{array}{c}\text { Conc. } \\
\text { (ppm) }\end{array}$ & $\begin{array}{c}\text { Free prolin } \\
\mathbf{m g} / \mathbf{g}\end{array}$ & $\begin{array}{c}\text { Total indoles } \\
\mathbf{m g} / \mathbf{g}\end{array}$ & $\begin{array}{c}\text { Ascorbic acid } \\
\mathbf{m g} / \mathbf{1 0 0 g}\end{array}$ & $\begin{array}{c}\text { Free phenoles } \\
\mathbf{m g} / \mathbf{g}\end{array}$ & $\begin{array}{c}\text { Total phenoles } \\
\mathbf{m g} / \mathbf{g}\end{array}$ \\
\cline { 2 - 7 } & - & 6.12 & 10.95 & 10.15 & 2.69 & 5.21 \\
\cline { 2 - 7 } & 50 & 6.65 & 15.19 & 12.65 & 2.66 & 6.14 \\
\cline { 2 - 7 } & 100 & 6.73 & 18.17 & 13.10 & 2.42 & 8.25 \\
\cline { 2 - 7 } & 400 & 7.56 & 19.18 & 14.65 & 2.40 & 8.69 \\
\cline { 2 - 7 } & 800 & 8.03 & 19.48 & 15.02 & 2.35 & 8.93 \\
\hline \multirow{4}{*}{ L.S.D. 0.05 } & - & $\mathbf{0 . 5 3}$ & $\mathbf{1 . 8 3}$ & 12.10 & 2.65 & 6.55 \\
\hline
\end{tabular}

\subsubsection{The enzymatic activity}

Data in Table (7) indicate that the plants of N.oleander sprayed with glyphosate increased the leaf content of antioxidant enzymes such as peroxidase, catalase, polyphenol oxidase and ascorbic acid oxidase than unsprayed control. Glyphosate at 200 and $400 \mathrm{ppm}$ induced the higher increase of enzymatic activity. The relative increase percentages were 21.15 and $26.18 \%$ for peroxidase; 39.15 and $43.12 \%$ for catalase; 29.11 and $32.06 \%$ for polyphenol oxidase and 19.03 and $23.02 \%$ for ascorbic acid oxidase over the check, respectively.
Moreover, the infection of plants with dodder reduces the different metabolic processes which are responsible for normal plant growth. The adverse effect on the synthesis of chlorophyll a, b, carotenoids, xanthophylls, sugars, prolin and plant auxin concentration which occurred as a result of dodder infection was reduced by treating the plants with glyphosate used in this investigation. The positive effect of glyphosate on the activities of catalase, peroxidase, polyphenol oxidase and ascorbic acid oxidase may be due to rather sensitive effect of glyphosate on these enzymes. In this connection, Yin et al. ( 2008 ) found that

Table (7): Effect of glyphosate herbicide on antioxidant enzymes of N.oleander leaves.

\begin{tabular}{|l|c|c|c|c|c|}
\hline \multirow{3}{*}{ Treatment } & Conc. $(\mathbf{p p m})$ & $\begin{array}{c}\text { Peroxidase } \\
\text { activity }\end{array}$ & $\begin{array}{c}\text { Catalase } \\
\text { activity }\end{array}$ & $\begin{array}{c}\text { Polyphenol } \\
\text { oxidase } \\
\text { activity }\end{array}$ & $\begin{array}{c}\text { Ascorbic acid } \\
\text { oxidase } \\
\text { activity }\end{array}$ \\
\hline Check & - & 100.00 & 100.00 & 100.00 & 100.00 \\
\cline { 2 - 6 } Glyphosate & 50 & 111.21 & 131.01 & 120.15 & 109.22 \\
\cline { 2 - 6 } & 100 & 113.33 & 136.21 & 126.02 & 111.25 \\
\cline { 2 - 6 } & 200 & 121.15 & 139.15 & 129.11 & 119.03 \\
\cline { 2 - 6 } & 400 & 126.18 & 143.12 & 132.06 & 123.02 \\
\cline { 2 - 6 } & 800 & 113.26 & 133.44 & 128.00 & 111.64 \\
\cline { 2 - 6 } L.S.D. 0.05 & - & $\mathbf{7 . 3 1}$ & $\mathbf{5 . 8 2}$ & $\mathbf{5 . 5 4}$ & $\mathbf{9 . 0 2}$ \\
\hline
\end{tabular}



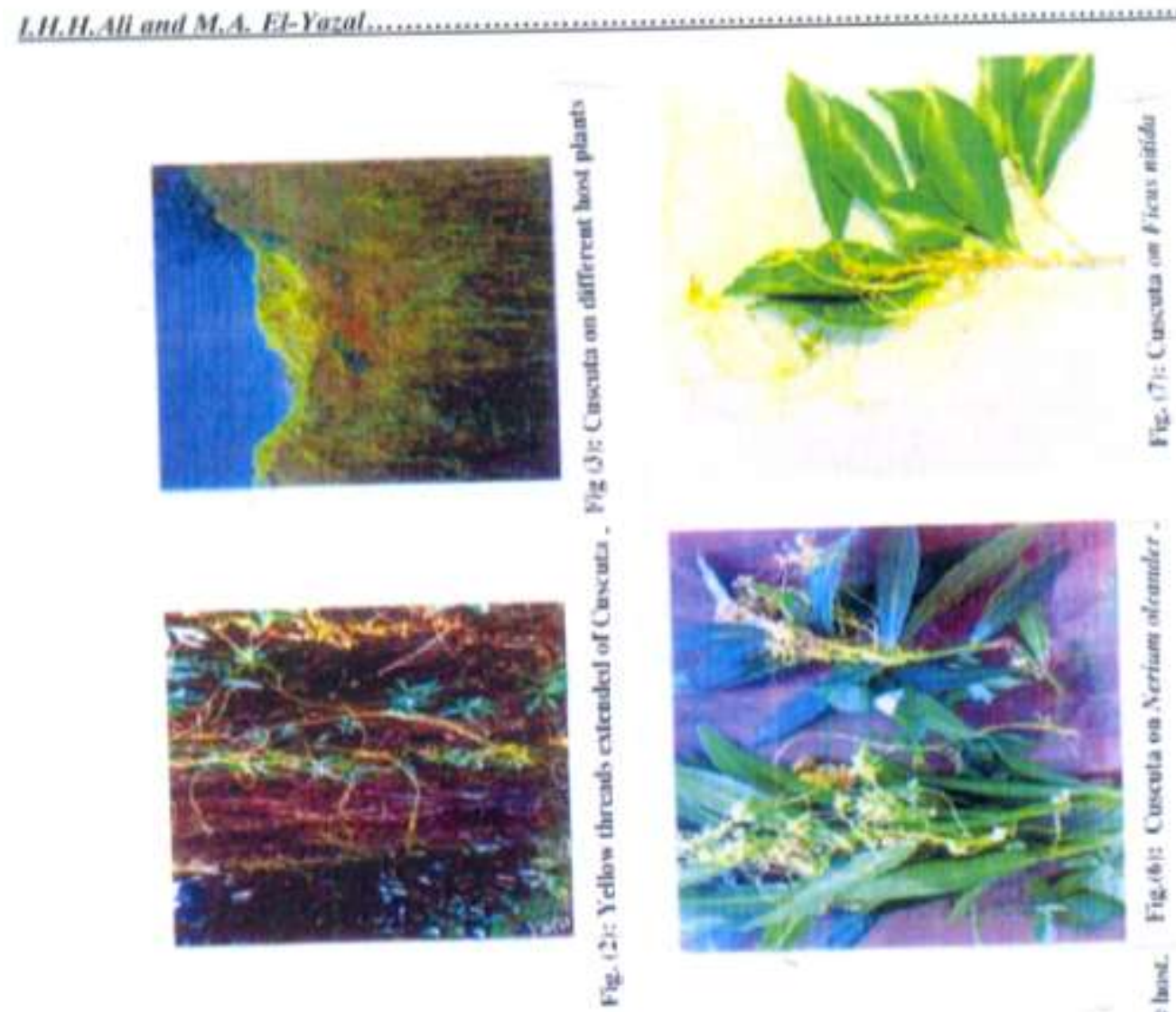

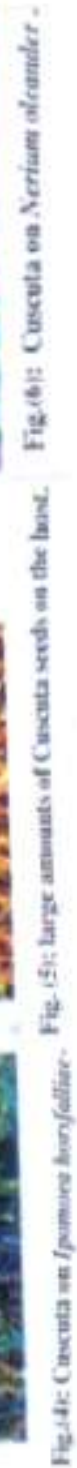


isoproturon-induced oxidative stress resulted in a substantial change in activities of the majority of antioxidant enzymes including superoxide dismutase (SOD), peroxidase (POD), catalase (CAT) and ascorbate peroxidase (APX). Activities of the antioxidant enzymes showed a general increase at low isoproturon concentrations and a decrease at high isoproturon concentrations. Also, similar results were obtained by El-Saht (2001) using metribuzin herbicide on maize plants and by Moldes et al. (2008) using glyphosate herbicide on soybean plants.

Generally it is clear that glyphosate enhanced all the biochemical parameters in the leaf of host plant $N$. oleanderand there are no adverse effect on the host plant at the levels of application with glyphosate at 200 and $400 \mathrm{ppm}$.

\subsection{Survey study on $C$. campestris}

The survey study was aiming to identify the susceptible hosts of ornamental plants attacked by C.campestris in Fayoum Governorate. $C$. campestris was found parasitizing eleven ornamentals belonging to different plant families. Some of these hosts were previously recorded by Abu-Irmaileh (1987) and Hock et al. (2008) such as Canna indica L., Ocinum basilicum L., Ixora acuminata L., Hibiscus mutabilis L., Majorana hortensis Jacq. and Celosia argentea Dc. AlMenoufi et al. (1985) recorded the occurrence of this parasite on some of the previous hosts in addition to weed and crop plants in the delta region. Also, Ali (1996) reported the presence of this species on Dodonia vescosa L., Duranta plumieri Jacq., Luffa aegyptiaca L., Tropaeolum majus L. and Sesbania aegyptiaca L. in Middle Egypt. Some others were new recorded of $C$. campestris in Egypt included five ornamentals: Nerium oleander L., Ficus nitida L., Adhatoda vasica L., Ipomoea horsfalliae L. and Cestrum diurnum L. as shown in Table (8) and Figs. (1 to 7).

Table (8): Susceptible hosts of ornamentals by C.campestris.

\begin{tabular}{|c|c|}
\hline \multicolumn{2}{|c|}{ Ornamental plants } \\
\hline A. Old recording & B. New recording \\
\hline 1. Canna indica $\mathrm{L}$. & 1. Adhatoda vasica $\mathrm{L}$. \\
\hline 2. Celosia argentea Dc. & 2. Cestrum diurnum $\mathrm{L}$. \\
\hline 3. Hibiscus mutabilis L. & 3. Ficus nitida $\mathrm{I}$ \\
\hline 4. Ixora acuminata $\mathrm{L}$. & 4. Ipomoea horsfalliae \\
\hline 5. Majorana hortensis Jacq & \\
\hline 6. $\mathrm{Oct}$ & \\
\hline
\end{tabular}

\section{REFERENCES}

Abu-Irmaileh B.E. (1987). Eastern dodder (Cuscuta monogyna Vahl.) distribution, host range and its response to glyphosate applications.Proc. of the $4^{\text {th }}$ ISPFP, Marburg. $1-10$.

Abu-Irmaileh B.E. and Fuilk J.E. (1989). Using glyphosate to control eastern dodder on citrus in Jordan. Hort Sci. 24(2): 311-312.

Ali I.H.H. (1996). Effect of certain herbicides and some plant extracts on dodder (Cuscuta spp.). Ph.D. Thesis, Fac. Agric., Fayoum, Cairo Univ., Egypt.

Ali I.H.H. and El-Yazal M.A. (2003). Effect of glyphosate and stomp herbicides on dodder control, growth, yield and chemical constituents of fenugreek plants (Trigonella foenum - graecum L.). Egypt. J. Appl. Sci., 18(12): 24-37.

Al-Menoufi O.A., Rezk M.A., Mostafa A.K. and El-Shair S. (1985). Studies on the parasitism of Cuscuta spp. 4. Cuscuta species and some of their hosts in the Nile Delta region. J. Agric. Sci. Mansoura Univ., 10(3): 847849.

A.O.A.C. (1995). Official methods of analysis, published by the A.O.A.C. Washington, D.C., U.S.A.

Bates L.S., Waldren R.P. and Teare I.D. (1973). Rapid determination of free proline for water stress studies plant and soil, 39: 205207.

Beers R.F. and Sizer I.W. (1952). A spectrophotometric method for measuring the breakdown of hydrogen peroxide by catalase. J. Biol. Chem., 195: 133.

Bewick T.A., Binning L.K. and Dana M.N. (1988). Post attachment control of swamp dodder (Cuscuta gronovii) in cranberry (Vaccinium macrocarpon) and carrot (Daucus carota). Weed Technol. 2(2): 166169.

Christopher M.K., Jed B.C. and Richard A.R. (2009). Swamp dodder (Cuscuta gronovii) management in carrot production. Weed Technol., 23(3): 408-411.

Dawson C.R. and Magee R.J. (1955). Ascorbic acid oxidase, p. 831-835. In: S.P. Colowick (Ed.). Methods in enzymology, Vol. II. Academic Press, New York.

Dawson J.H. (1972). Inhibitor of microbial enzyme prolongs dodder control with chlorpropham. Weed Sci. 20(5): 465-467. 
Dawson J.H. (1987). Cuscuta (Convolvulaceae) and its control. Proc. of the $4^{\text {th }}$ ISPFP, Marburg, 137-148.

Dawson J.H. (1990). Dodder (Cuscuta spp.) control in newly seeded alfalfa (Medicago sativa) with glyphosate. Weed Technol., 4(4): 880-885.

Dawson J.H. and Saghir A.R. (1983). Herbicides applied to dodder (Cuscuta spp.) after attachment to alfalfa (Medicago sativa). Weed Sci., 31(4): 465-471.

El-Saht H.M., Hassaneen M.N. and Bassyoni F.M. (1994). Effect of metribuzin herbicide on nitrogen, pigments, protease and nitrate resductase activity of normal and in $\mathrm{NaCl}$ stressed castor bean and maize plants. Biol. Plant. 36, 267.

El-Saht H.M. (2001). Metribuzin herbicide induced a defense mechanism in normal and $\mathrm{NaCl}$-stressed castor bean and maize plants. Egypt. J. Hort. 28, No. 2, pp. 277-290.

Gimesi A. (1966). Dodder eradication with "Reglone". Outlook on Agric. 5: 28-34.

Gimesi A. (1987). Chemical control of Cuscuta species. Proc. of the $4^{\text {th }}$ ISPFP, Marburg, 249-252.

Giannopolitis C.N. (1979). Inhibition of seed germination and early stem elongation of Cuscuta australis by ethofumesate. Weed Res., 19: 95-100.

Graph S., Kleifeld Y. and Friedman Y. (1987). The effect of propyzamide on field dodder (Cuscuta campestris Yunker.). Proc. of the $4^{\text {th }}$ ISPFP, Marburg, 277-284.

Hock S.M.,Wieck O.G. and Knezevic S.Z. (2008). Glyphosate dose affected control of field dodder (Cuscuta campestris) in the tropics. Weed Technol., 22 (1): 151-155.

Larson P., Herio A., Klunsour S. and Asheim T.A. (1962). On the biogensis of some indoles compounds in Acetobacter xylimum. Physiol. Plant, 15: 552-565.

Maehly A.C. and Chance B.C. (1954). The assay of catalases and peroxidases. In D. Glick. Ed. Methods of Biochemical Analysis. Vol. I. Inter science publish. New York.

Michel K. A., Gilles J.K., Hamiltion P.A. and Freed S. (1956). Colorimetric method for determination of sugars and related substances. Analytical chemistry. 28(3): 186-192.

Moldes C.A., Medici L.O., Tsai S.M. and Azevedo R.A. (2008). Biochemical responses of glyphosate resistant and susceptible soybean plants exposed to glyphosate. Acta physiologiae plantarum. 30(4): 469-479.

Parker C. and Wilson A.K. (1986). Parasitic weeds and their control in the near east. FAO Plant Prot. Bull. 34(2): 83-98.

Snedecor G.W. and Cochran W.G. (1980). Statistical methods. $7^{\text {th }}$ Ed., Iowa State Univ. press, Ames, Iowa, USA.

Soliman I.E. and Abd El-Hamid M.M. (2009). Effect of sowing methods and some weed control treatments on dodder control in clover crop. J. Agric. Sci. Mansoura Univ., 34(4): 3211-3221.

Taneja S.R. and Sachar R.C. (1974). Induction of polyphenol oxidase in germinating wheat seeds. Phytochemistry, 13: 2695-2702.

Welburn A.R. and Lichtenthaler H. (1984). Formula and program to determine total carotenoids and chlorophyll $\mathrm{a}$ and $\mathrm{b}$ of leaf extracts in different solvents. In "Advances in photosynthesis research" (Sybesma C. Ed.) Vol. II, pp. 9-19.

Yin X., Jiang L., Song N.H. and Yang H. (2008). Toxic reactivity of wheat (Triticum aestivum) plants to herbicide isoproturon. J. Agric. Food Chem., 56(12): 4825-4831.

Zahran M.K., Hassanein E.E., El-Wekil H.R. and Yehia Z.R. (1995). Investigation into post attachment control of Cuscuta on duranta evergreen shrub. Fayoum J. Agric. Res. \& Dev., 9(1): 203-214. 


\section{تأثير مبيد الحشائش الجليفوسيت على مكافحة الحامول وكذلك المكونات الكيميائية والانزيمات المضادة للاكسدة لنباتات الدفلة مع حصر المدى العوائلى لنباتات الزينة في الفيون الفيوم}

\section{* ابراهيم حامد حسين على - عمد احمد سيف اليزل}

$$
\text { قسم وقاية النبات، * قسم النبات الزر اعى- كلية الزر اعة - جامعة الفيوم ـ مصر }
$$

\section{ملخص بتر

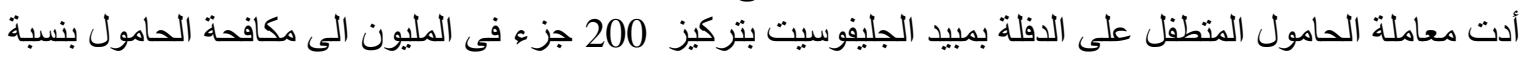

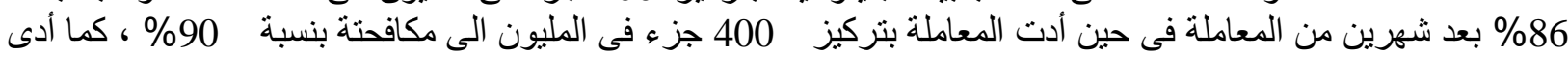

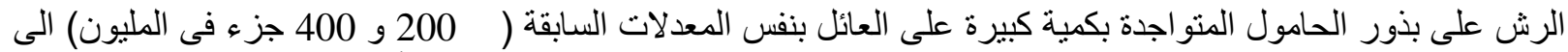

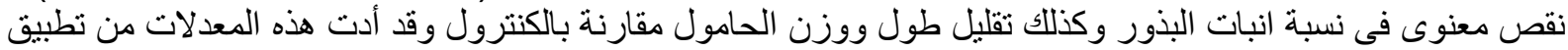

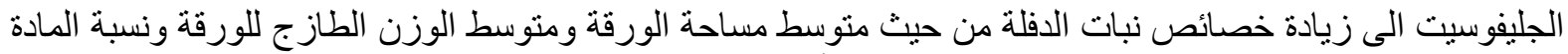

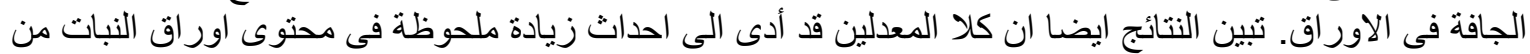

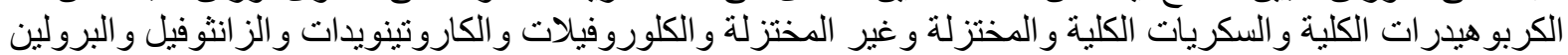

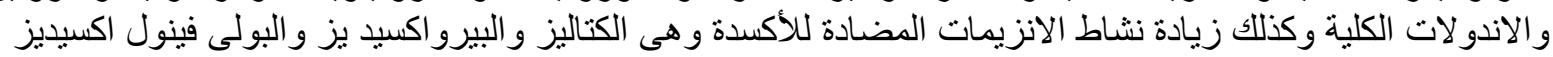

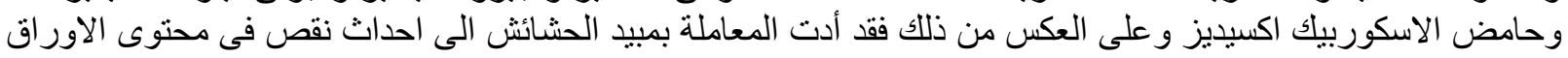

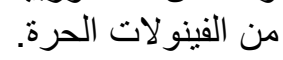

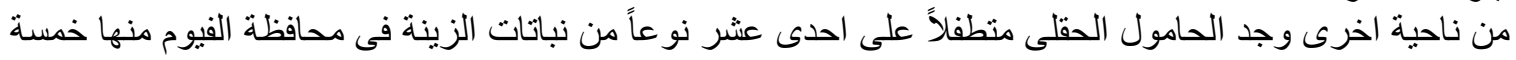

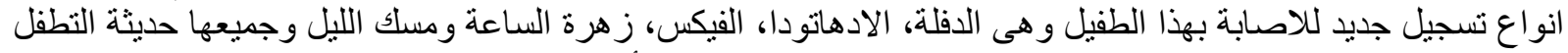

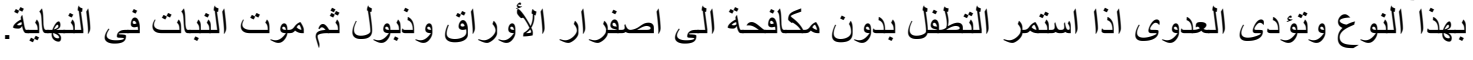

